\title{
Analisis produksi kelapa sawit kelompok tani di Desa Purwodadi Kecamatan Tebing Tinggi Kabupaten Tanjung Jabung Barat
}

\author{
Hanifah Rosa*; Zulgani; Etik Emiyati
}

\author{
Prodi Ekonomi Pembangunan, Fak. Ekonomi dan Bisnis, Universitas Jambi \\ *E-mail korespondensi: hanifahrosa770@gmail.com
}

\begin{abstract}
The purpose of this study is to determine the factors that influence the production of oil palm farmer groups in Purwodadi Village, Tebing Tinggi District, Tanjung Jabung Timur Regency. The data used in this study are primary data obtained utilizing field research sourced from oil palm farmers in Purwodadi Village, Tebing Tinggi District, Tanjung Jabung Barat Regency as samples. The sampling method used in this study is random sampling. The data were analyzed using descriptive and quantitative analysis methods, using multiple linear regression analysis tools. The results of the study found that the socio-economic characteristics of oil palm farmers in Purwodadi Village were based on gender, education level, work experience, number of workers, land area, capital, and coconut production. palm. The results of the data using multiple linear regression to calculate the oil palm production of farmer groups in Purwodadi Village which is influenced by the variable Capital with a coefficient of 0.420714, the variable of land area with a coefficient of 0.903379, and the variable of Labor with a coefficient of 0.255833 at the 95\% confidence level has a positive effect and farmer groups in Purwodadi Village are significant for palm oil production if each variable is added.
\end{abstract}

Keywords: Production, Charactiristics of oil palm farmers

\begin{abstract}
Abstrak
Tujuan penelitian ini adalah untuk faktor- faktor yang mempengaruhi produksi kelapa sawit kelompok tani di Desa Purwodadi, Kecamatan Tebing Tinggi, Kabupaten Tanjung Jabung Timur. Data yang digunakan dalam penelitian ini adalah data primer yang diperoleh dengan cara penelitian lapangan yang bersumber dari petani kelapa sawitdi Desa Purwodadi Kecamatan Tebing Tinggi Kabupaten Tanjung Jabung Barat sebagaisampel. Metode penarikan sampel yang digunakan dalam penelitian ini adalah Random Sampling. Data dianalisis dengan metode analisis deskriptif dan kuantitatif, menggunakan alat analisis regresi linier berganda.Hasil penelitian menemukan bahwa karakteristik sosial ekonomi petani kelapa sawit di Desa Purwodadi berdasarkan jenis kelamin, tingkat pendidikan, pengalaman kerja, jumlah tenaga kerja, luas lahan, modal dan produksi kelapa sawit. Hasil data dengan regresi linier berganda untuk menghitung produksi kelapa sawit kelompok tani di Desa Purwodadi yang di pengaruhi dengan variabel Modal dengan koefisien sebesar 0.420714, variabel Luas Lahan dengan koefisien sebesar 0.903379 dan variabel Tenaga Kerja dengan koefisien sebesar 0.255833 pada tingkat kepercayaan $95 \%$ berpengaruh positif dan signifikan terhadap produksi kelapa sawit kelompok tani di Desa Purwodadi jika masing-masing variabel ditambah.
\end{abstract}

Kata kunci: Produksi, Karakteristik petani kelapa sawit

\section{PENDAHULUAN}

Daerah-daerah di Indonesia hampir bisa dikatakan sebagian besar melakukan budidaya perkebunan kelapa sawit. Provinsi yang menghasilkan produksi CPO terbesar di 
Indonesia pada tahun 2016 adalah Provinsi Riau 6,7 juta ton $(28,14 \%)$, kemudian berturutturut Provinsi Sumatera Utara 5,3 juta ton $(19,01 \%)$, Sumatera Selatan 3,3 juta ton $(12,24 \%)$, Kalimantan Tengah 2,6 juta ton $(9,26 \%)$ dan Jambi 2,2 juta ton $(7,88 \%)$. Perkembangan produksi CPO semakin meningkat sesuai minat masyarakat yang telah mengubah lahan pertaniannya menjadi perkebunan kelapa sawit. Pada Provinsi Jambi perkebunan kelapa sawit menyumbang sekitar 12 persen per tahun untuk pendapatan atau PDRB.

Harga kelapa sawit di Jambi pada laporan triwulan terus mengalami peningkatan. Harga rata-rata TBS usia 10 tahun Rp 1826.23 per kg, meningkat 17.95 persen dari harga triwulan lalu. Sementara itu harga CPO di Jambi sebesar 8261.02 per kg atau meningkat

18.28 persen. Harga rata-rata kelapa sawit di tingkat Internasional juga menunjukkan perbaikan yautu sebesar USD 782.25 per metrik ton atau meningkat 8.35 persen dibandingkan harga CPO dunia sebesar 9.45 persen (BPS Jambi dalam angka, 2016). berdasarkan data dari Badan Statistik Pusat Jambi, bahwa kontribusi sektor pertanian terhadap PDB pada tahun 2015 berada pada urutan ketiga setelah sektor industri pengolahan dan sektor perdagangan, hotel, dan restoran. Dari total PDB pada tahun 2016 yakni Rp 2.618.932 Miliar, sektor industri pengolahan memiliki kontribusi tertinggi yaitu sebesar Rp 707.481,7 Miliar atau sekitar 25,55 persen, dan sektor perdagangan, hotel, dan restoran berkontribusi sebesar Rp 501.040,6 Miliar atau sekitar 18,09 persen yang berada pada urutan kedua. Sedangkan kontribusi sektor pertanian adalah sebesar Rp 339.560,8 Miliar atau sebesar 12,26 persen (BPS Jambi dalam angka, 2016).

Provinsi Jambi pada tahun 2015 sektor pertanian memiliki kontribusi tertinggi terhadap PDRB yaitu sebesar Rp 6.449.192,52 Juta atau sekitar 29,34\% dari total PDRB yang sebesar Rp 21.979.277 Juta. Dimana sebesar Rp 3.186.853,36 Juta atau sekitar 49,41\% dari sektor pertanian tersebut merupakan kontribusi dari subsektor perkebunan diantaranya jenis komoditi perkebunan adalah karet, kelapa sawit, kelapa dalam, kelapa hibrida, kopi robusta, kopi arabika, lada, cengkeh, coklat, pinang, kapuk, kemiri, jarak, aren, vanili, teh, tebu, tembakau dan nilam. Tanaman perkebunan yang paling banyak diusahakan di Provinsi Jambi pada tahun 2015 adalah tanaman karet dengan luas 662.213 Ha, sedangkan diurutan kedua adalah tanaman sawit dengan luas 593.433 Ha. Akan tetapi, produksi tanaman karet lebih rendah bila dibandingkan dengan produksi tanamankelapa sawit. Dimana produksi tanaman karet adalah 323.271 Ton, sedangkan produksi tanaman kelapa sawit adalah 1.555.697 Ton. Artinya tanaman kelapa sawit lebih produktif bila dibandingkan dengan tanaman karet.

Tahun 2017 di Kabupaten Tanjung Jabung Barat komoditi perkebunan yang banyak diusahakan adalah tanaman kelapa sawit dengan luas areal mencapai 61.806 Haatau 42,78\% dari total keseluruhan luas tanaman perkebunan di Kabupaten Tanjung Jabung Barat. Hal ini membuktikan bahwa tanaman kelapa sawit (Elaeis guineassis) merupakan tanaman penghasil utamaminyak nabati yang mempunyai produktivitas lebih tinggi dari pada tanaman penghasil minyak nabati lainnya. Tanaman yang berasal dari Afrika Barat dan Amerika ini termasuk tanaman yang lebih tahan terhadap serangan hama danpenyakit. Kelapa sawit mempunyai peranan yang cukup strategis dalam Indonesia, hal inidikarenakan kelapa sawit merupakan bahan baku utama minyak goreng, komoditas andalan ekspor nonmigas dan mampu menciptakan lapangan kerja (Putranto, 2012).

Besarnya produksi tanaman perkebunan kelapa sawit dibandingkan dengan jenis tanaman perkebunan lainnya, yaitu sebesar 131.235 Ton atau $64,28 \%$ dari total keseluruhan produksi tanaman perkebunan di Kabupaten Tanjung Jabung Barat. Upaya peningkatan produksi kelapa sawit terus dilakukan melalui peningkatan luas areal untuk memenuhi kebutuhan pangan (minyak nabati) dan kebutuhan industri dalam negeri, meningkatkan ekspor, dan meningkatkan kesejahteraan petani. Sebagian besar produksi kelapa sawit tersebut dihasilkan oleh perkebunan rakyat, salah satu diantaranya dalam bentuk kelompok usahatani yang dikelola langsung oleh Koperasi Unit Desa (Daim, 2003). 
Luas tanaman perkebunan di Desa Purwodadi Kecamatan Tebing Tinggi dengan jenis tanaman kelapa sawit yang mendominasi luas perkebunan di Kecamatan Tebing Tinggi hingga mencapai luas tanaman perkebunan kelapa sawit sebesar 11.265 hektar. Desa Purwodadi yang memiliki luas tanaman kelapa sawit ke tiga setelah Desa Teluk Pengkah dan Desa Kelagian yaitu dengan luas 1.930 hektar atau 17,13 persen dari luas tanaman perkebunan kelapa sawit di Kecamatan Tebing Tanggi Kabupaten Tanjung Jabung Barat (BPS Tebing Tinggi dalam angka, 2017). kelebihan yang dimiliki Kecamatan Tebing Tanggi dalam melakukan pengelolaan perkebunan kelapa sawit dibandingkan dengan kecamatan-kecamatan yang ada di Kabupaten Tanjung Jabung Barat, yaitu dengan memperdayakan kelompok tani. Kelompok tani perkebunan kelapa sawit yang paling berkembang dan berjalan dengan lancar adalah kelompok tani yang adadi Desa Purwodadi. Sehingga mampu memberdayakan hasil perkebunan ke bidang usahalain.

Produksi tanaman perkebunan menurut jenis tanaman Desa/ Kelurahan di Kecamatan Tebing Tinggi dengan jumlah produksi tanaman perkebunan kelapa sawit pada tahun 2017 sebesar 200.102 ton/ tahun. Jumlah produksi ini jauh meningkat dari tahuntahun sebelumnya yaitu sebesar 26.448 ton/ tahun pada tahun 2016. Hal inidikarenakan upaya peningkatan produksi tanaman perkebunan kelapa sawit di KecamatanTebing Tinggi dilakukan dengan program swasembada pangan di bidang hasil produksi bahan minyak nabati (Palm Oil). pola kerjasama yang dilakukan oleh masyarakat petani tanaman perkebunan kelapa sawit bermitra dengan KUD sangat membantu sekali, baik dalam hal permodalan maupun pemasaran hasil produksi kelapa sawit bisa langsung terorganisis dengan baik. Adapun petani tanaman perkebunan kelapa sawit di Kabupaten Tanjung Jabung Barat yang telah menerapakan pola kerja sama dengan KUD adalah DesaPurwodadi Kecamatan Tebing Tinggi. Desa Purwodadi merupakan desa perintisan dari program transmigrasi yang dicanangkan oleh pemerintah orde baru. Namun sesuai perkembangannya Desa Purwodadi menjelma Desa percontohan yang tak hanya di Kabupaten Tanjung Jabung Barat saja bahkan sampai tingkat Provinsi dan Nasional yang mampu mencapai prestasi di dalam hal ketahanan pangan. Desa Purwodadi telah membentuk KUD yang mewadahi berbagai sektor kegiatan ekonomi masyarakat dalam upaya peningkatan kesejahteraan anggota. Potensi ataupun produk unggulan yang dimiliki oleh Desa Purwodadi di bidang pertanian berupa tanaman perkebunan kelapa sawit. KUD memfasilitasi permodalan kepada masyarakat Desa Purwodadi melalui pinjaman lunak dengan tingkat suku bunga rendah, diantaranya yang ikut pro aktif dari kalangan pedagang, industri rumah tangga, UMKM, biro jasa, dan pertanian. Peran KUDdi Desa Purwodadi sangat membantu perekonomian masyarakat terutama masyarakat petani perkebunan kelapa sawit.

\section{METODE}

Metode penelitian adalah pengetahuan tentang cara-cara atau metode-metode atau desain atau tehnik yang diterapkan dalam melaksanakan suatu penelitian. Dengan demikian, metode penelitian adalah ilmu pengetahuan tentang berbagai cara atau metode atau tehnik yang dipergunakan dalam melaksanakan suatu penelitian ilmiah, Amir, Yulmardi dan Junaidi (2009). Metode penelitian yang digunakan dalam penelitian ini menggunakan data primer. Data primer adalah data yang diambil langsung pada masyarakat dengan menggunakan kuisionaer dan hasil obsirvasi.Data yang digunakan dalam penelitian ini terdiri dari dua jenis data yaitu jenis data primer dan data sekunder.

\section{Data primer}

Data primer adalah suatu data-data yang diambil langsung oleh sumbernya, tanpa ada perantara sumber yang dimaksud dapat berupa benda, situasi, atau manusia. Adapun data primer yang di peroleh melalui observasi langsung dari hasil angket dengan di 
sebarkannya pada responden kelompok tani di Desa Purwodadi Kecamatan TebingTinggi Kabupaten Tanjung Jabung Barat.

\section{Data sekunder}

Data sekunder berupa data yang diperoleh dari instansi pihak terkait yang merupakan hasil olahan dari pihak tersebut. Data yang dibutuhkan dalam penelitian ini adalah jumlah modal, luas lahan, dan tenaga kerja serta produksi kelapa sawit kelompoktani yang ada di Desa Purwodadi Kecamatan Tebing Tinggi Kabupaten Tanjung JabungBarat.

\section{Populasi penarikan sampel}

Menurut Sugiyono (2011), Populasi adalah wilayan generalisasi yang terdiri atas objek atau subjek yang mempunyai kualitas dan karakteristik tertentu yang ditetapkan oleh peneliti untuk dipelajari dan kemudian ditarik kesimpulannya. Daerah penelitian yang dipilih yaitu Desa Purwodadi Kecamatan Tebing Tinggi dengan secara sengaja (purposive). Pertimbangan daerah tersebut dijadikan sebagai lokasi penelitian adalah berdasarkan data kelompok tani yang aktif memberikan kontribusi terhadap jumlah produksi kelapa sawit yang lebih maksimum. Maka diambil sampel penelitian sebagai reponden yaitu 38 kelompok tani di Desa Purwodadi Kecamatan Tebing Tinggi. Kelompok tani yang tersebar di Desa Purwodadi akan menjadi objek penelitian atau menjadi responden langsung dengan membagikan kuesioner kepada 38 kelompok tani secara acak (random sampling).

Fungsi produksi Cobb-Douglas dalam ilmu ekonomi berfungsi sebagai suatu fungsi yang menunjukkan hubungan antara hasil fisik (Output) dengan faktor produksi (Input) yang sering ditulis dalam matematika $Y=f\left(X_{1}, X_{2}, X_{3, \ldots}, X_{n}\right.$. Metode analisis data yang digunakan adalah deskriftif kuantitatif. Untuk menjawab pertanyaan pertama maka digunakan alanisis deskriftif kualitatif yang merupakan analisis yang digunakan. Deskriftif gambaran mengenai pengaruh modal, luas lahan, dan tenaga kerja terhadap produksi kelapa sawit kelompok tani di Deurwodadi Kecamatan Tebing Tinggi Kabupaten Tanjung Jabung Barat. Untuk menguji pertanyaan yang kedua digunakan fungsi produksi CobbDouglas yang diubah menjadi regresi linier berganda dengan cara melogaritmakan persamaan tersebut dengan rumus sebagai berikut : (Soekartawi, 2003)

$$
\mathrm{Q}=\mathrm{A} \mathrm{L}^{\mathrm{a}} \mathrm{K}^{\mathrm{b}} \quad \mathrm{Q}=\boldsymbol{f}(\mathrm{K}, \mathrm{L}, \mathrm{R}, \mathrm{T}) \mathrm{Y}=\boldsymbol{\beta} 0+\beta 1 \mathrm{X} 1+\beta 2 \mathrm{X} 2+\beta 3 \mathrm{X} 3+\varepsilon
$$

$\log Y=\log \beta 0+\log \beta 1 X 1+\log \beta 2 X 2+\log \beta 3 X 3+\varepsilon$

Dimana:

Log $\mathrm{Y}=$ Produksi kelapa sawit

$\beta 0=$ Konstanta

$\beta 1=$ Koefisien regresi

$\mathrm{X}=$ Modal

$\mathrm{X} 2=$ Luas lahan

$\mathrm{X} 3=$ Tenaga kerja

$\mathrm{E} \quad=$ Error term

\section{HASIL DAN PEMBAHASAN}

\section{Karakteristik responden berdasarkan jenis kelamin}

Karakteristik responden berdasarkan jenis kelamin yang menjadi petani di Desa PurwodadiKecamatan Tebing Tinggi Kabupaten Tanjung Jabung Barat dapat di lihat sebagai berikut : 
Tabel 1. Karakteristik responden berdasarkan jenis kelamin

\begin{tabular}{llcc}
\hline \multirow{2}{*}{ No } & Jenis kelamin & Jumlah responden & Persentase (\%) \\
\hline 1 & Laki - Laki & 26 & 68 \\
2 & Perempuan & 12 & 32 \\
\hline & Total & $\mathbf{3 8}$ & $\mathbf{1 0 0}$ \\
\hline
\end{tabular}

Sumber : Data diolah, 2018

Berdasarkan Tabel 1. menjelaskan bahwa dari 38 responden petani di Desa PurwodadiKecamatan Tebing Tinggi Kabupaten Tanjung Jabung Barat dengan jenis kelamin laki-laki menunjukkan jumlah sebanyak 26 orang atau 68\%, sedangkan yang berjenis perempuan sebanyak 12 orang atau $32 \%$. Hal ini menunjukkan bahwa sebagian besar responden dalam penelitian ini adalah berjenis kelamin laki-laki.

\section{Karakteristik responden berdasarkan tingkat pendidikan}

Karakteristik respon berdasarkan tingkat pendidikan yang menjadi petani di Desa PurwodadiKecamatan Tebing Tinggi Kabupaten Tanjung Jabung Barat dapat di lihat sebagai berikut :

Tabel 2. Karakteristik responden berdasarkan tingkat pendidikan

\begin{tabular}{llcc} 
No & Tingkat pendidikan & Jumlah responden & Persentase \\
\hline 1 & SD & 7 & 18 \\
2 & SLTP & 11 & 29 \\
3 & SLTA & 18 & 47 \\
4 & S1 & 26 & \\
\hline Total & $\mathbf{6 2}$ & $\mathbf{1 0 0}$ \\
\hline
\end{tabular}

\section{Sumber Data diolah, 2018}

Tabel 2 menjelaskan bahwa dari 38 responden petani di Desa Purwodadi Kecamatan Tebing Tinggi Kabupaten Tanjung Jabung Barat dengan tingkat pendidikan SD, SLTP, dan SLTA dan tingkat perguruan tinggi (S1) semuanya menjadi responden, dengan responden tingkat pendidikan SD menunjukkan jumlah sebanyak 7 orang atau 18\%, tingkat pendidikan SLTP berjumlah 11 orang atau 29\%, tingkat pendidikan SLTAberjumlah 18 orang atau $47 \%$ dan tingkat pendidikan perguruan tinggi untuk S1 sebanyak2 orang atau $6 \%$. Hal ini menunjukkan bahwa sebagian besar responden dalam penelitianini adalah dari tingkat pendidikan SLTA.

\section{Karakteristik responden berdasarkan pengalaman kerja}

Karakteristik responden berdasarkan pengalaman kerjayang menjadi petani di Desa PurwodadiKecamatan Tebing Tinggi Kabupaten Tanjung Jabung Baratdapat di lihat sebagai berikut :

Tabel 3. Karakteristik responden berdasarkan pengalaman kerja

\begin{tabular}{lccc}
\hline No & Pengalaman kerja (tahun) & Jumlah responden & Persentase $(\boldsymbol{\%})$ \\
\hline 1 & $1-10$ & 8 & 21 \\
2 & $11-20$ & 12 & 32 \\
3 & $21-30$ & 14 & 37 \\
4 & $\geq 31$ & 4 & 10 \\
\hline & Total & $\mathbf{3 8}$ & $\mathbf{1 0 0}$ \\
\hline
\end{tabular}

Sumber: Data diolah, 2018 
Berdasarkan Tabel 3. menjelaskan bahwa dari 38 responden petani di Desa PurwodadiKecamatan Tebing Tinggi Kabupaten Tanjung Jabung Barat dengan pengalaman kerja $1-10$ tahun menunjukkan jumlah sebanyak 8 orang atau $21 \%$,pengalaman kerja $11-20$ tahun sebanyak 12 orang atau $32 \%$, dan yang pengalaman kerja 21 - 30 tahun sebanyak 14 orang atau 37\%, sedangkanpengalaman kerja $\geq 31$ tahun sebanyak 4 orang atau $10 \%$. Hal ini menunjukkan bahwa sebagian besar responden dalam penelitian ini adalah dari masa kerja 21 - 30 tahun.

\section{Karakteristik responden berdasarkan jumlah tenaga kerja}

Karakteristik responden berdasarkan jumlah tenaga kerjayang menjadi petani di Desa PurwodadiKecamatan Tebing Tinggi Kabupaten Tanjung Jabung Barat dapat di lihat sebagai berikut :

Tabel 4. Karakteristik responden berdasarkan jumlah tenaga kerja

\begin{tabular}{|c|c|c|c|}
\hline No & Jumlah tenaga kerja (orang) & Jumlah responden & Persentase \\
\hline 1 & $\leq 5$ & 8 & 22 \\
\hline 2 & $6-10$ & 11 & 29 \\
\hline 3 & $11-15$ & 15 & 39 \\
\hline \multirow[t]{2}{*}{4} & $\geq 16$ & 4 & 10 \\
\hline & Total & 8 & 0 \\
\hline
\end{tabular}

Sumber : Data diolah, 2018

Berdasarkan Tabel 4. menjelaskan bahwa dari 38 responden petani di Desa Purwodadi Kecamatan Tebing Tinggi Kabupaten Tanjung Jabung Barat dengan jumlah tenaga kerja $\leq 5$ orangmenunjukkan jumlah sebanyak 8 orang atau $22 \%$, jumlah tenaga kerja 6 - 10 orang sebanyak 11 orang atau 29\%, dan jumlah tenaga kerja $11-15$ orang sebanyak 15 orang atau 39\%,sedangkanuntuk jumalah tenaga $\geq 16$ orang sebanyak 4 orang atau 10\%.Hal ini menunjukkan bahwa sebagian besar responden petani kopi dalam penelitian ini adalah dari jumlah tenaga kerja $11-15$ orang.

\section{Karakteristik responden berdasarkan luas lahan}

Karakteristik responden berdasarkan luas lahanyang menjadi lahan petani di Desa Purwodadi Kecamatan Tebing Tinggi Kabupaten Tanjung Jabung Barat dapat di lihat sebagai berikut:

Tabel 5. Karakteristik responden berdasarkan luas lahan

\begin{tabular}{cccc}
\hline No & Luas Lahan (Hektar) & Jumlah Responden & Persentase \\
\hline 1 & $2-4$ & 7 & 18 \\
2 & $5-8$ & 16 & 42 \\
3 & $9-12$ & 12 & 32 \\
4 & $\geq 13$ & 3 & 8 \\
\hline & Total & $\mathbf{3 8}$ & $\mathbf{1 0 0}$ \\
\hline
\end{tabular}

Sumber: Data diolah, 2018

Berdasarkan Tabel 5 menjelaskan bahwa dari 38 responden petani di Desa Purwodadi Kecamatan Tebing Tinggi Kabupaten Tanjung Jabung Barat dengan luas lahan 2- 4 hektar menunjukkan jumlah sebanyak 7 orang atau $18 \%$, luas lahan $5-8$ hektar sebanyak 16 orang atau $42 \%$, danluas lahan $9-12$ hektar sebanyak 12 orang atau $32 \%$, sedangkan luas lahan lebih dari 13 hektar sebanyak 3 orang atau $8 \%$. Hal ini menunjukkan bahwa sebagian besar responden dalam penelitian ini adalah dari luas lahan5 - 8 hektar. 


\section{Karakteristik responden berdasarkan modal}

Karakteristik responden berdasarkan modalyang menjadi modal petani di Desa Purwodadi Kecamatan Tebing Tinggi Kabupaten Tanjung Jabung Barat dapat di lihat sebagai berikut :

Tabel 6. Karakteristik responden berdasarkan modal

\begin{tabular}{llcc}
\hline No & Modal & Jumlah responden & Persentase \\
\hline 1 & $\leq 10$ & 14 & 27 \\
2 & $11-20$ & 9 & 24 \\
3 & $21-30$ & 9 & 24 \\
4 & $\geq 31$ & 6 & 15 \\
\hline & Total & $\mathbf{3 8}$ & $\mathbf{9 0}$ \\
\hline
\end{tabular}

Sumber : Data diolah, 2018

Berdasarkan Tabel 6 menjelaskan bahwa dari 38 responden petani di Desa Purwodadi Kecamatan Tebing Tinggi Kabupaten Tanjung Jabung Barat dengan modal $\leq$ 10 Juta rupiahmenunjukkan jumlah sebanyak 14 orang atau $37 \%$, modal $11-20$ Juta rupiahmenunjukkan jumlah sebanyak 9 orang atau 24\%, dan modal 21 - 30 Juta rupiah sebanyak 9 orang atau 24\%, sedangkan modal $\geq 31$ Juta rupiah sebanyak 6 orang atau $15 \%$. Hal ini menunjukkan bahwa sebagian besar responden dalam penelitian ini adalah dengan modal antara $\leq 10$ Juta rupiah.

\section{Responden berdasarkan produksi kelapa sawit}

Karakteristik responden berdasarkan produksi kelapa sawityang menjadi hasil petani di PurwodadiKecamatan Tebing Tinggi Kabupaten Tanjung Jabung Barat dapat di lihat sebagai berikut :

Tabel 7. Karakteristik responden berdasarkan produksi kelapa sawit

\begin{tabular}{cccc}
\hline No & Produksi kelapa sawit(ton) & Jumlah responden & Persentase(\%) \\
\hline 1 & $10-20$ & 6 & 15 \\
2 & $21-30$ & 20 & 53 \\
3 & $\geq 31$ & 12 & 32 \\
\hline & Total & $\mathbf{3 8}$ & $\mathbf{1 0 0}$ \\
\hline
\end{tabular}

Sumber : Data diolah, 2018

Berdasarkan Tabel 7. menjelaskan bahwa dari 38 responden petani di Desa Purwodadi Kecamatan Tebing Tinggi Kabupaten Tanjung Jabung Barat dengan produksi kelapa sawit 10 - 20 Tonmenunjukkan jumlah sebanyak 6 orang atau 15\%, produksi kelapa sawit 21 - 30 Tonmenunjukkan jumlah sebanyak 20 orang atau 53\%, dan produksikelapa sawit $\geq 31$ Ton sebanyak 12 orang atau 32\%. Hal ini menunjukkan bahwa sebagianbesar responden dalam penelitian ini adalah dengan produksi kelapa sawit antara 21 - 30ton.

\section{Analisis regresi linier berganda}

Hasil pengolahan fungsi Cobb-Douglas atau fungsi produksi yang dirubah dalam formulasi regresi linier berganda dengan Aplikasi Eviews versi 8.0 bertujuan untuk menentukan produksi kelapa sawit kelompok tani di Desa Purwodadi Kecamatan Tebing Tinggi Tanjung Jabung Barat. Sebagaimana formulasi fungsi Cobb-Douglas kemudian sederhanakan dalam bentuk regresi ini :

$\mathrm{Q}=\mathrm{A} \mathrm{L}^{\mathrm{a}} \mathrm{K}^{\mathrm{b}} \quad \mathrm{Q}=f(\mathrm{~K}, \mathrm{~L}, \mathrm{R}, \mathrm{T}) \mathrm{Y}=\boldsymbol{\beta} 0+\beta 1 \mathrm{X} 1+\beta 2 \mathrm{X} 2+\beta 3 \mathrm{X} 3+\varepsilon$ 


\section{$\log Y=\beta_{0}+\log X_{1}+\log X_{2}+\log X_{3}+e^{u}$}

Adapun faktor-faktor yang mempengaruhi tersebut adalah modal, luas lahandantenaga kerjasesuai tabel berikut ini :

Tabel 8. Hasil regresi linier berganda

\begin{tabular}{lllll}
\hline Variabel & Coefficient & Std Error & t - Statistic & Prob \\
\hline C & 17.79842 & 8.393674 & 8.393674 & 0.0014 \\
MD & 0.420714 & 0.726966 & 0.726966 & 0.0009 \\
LH & 0.903379 & 0.352763 & 0.352763 & 0.0051 \\
TK & 0.255833 & 0.315521 & 0.811599 & 0.0027 \\
R - & 0.470536 & & F-Statistic & 0.007198 \\
Squared & & & Prob (F & -0.000068 \\
Adjusted R & 0.635889 & & Statistic) \\
- Squared & & &
\end{tabular}

Sumber: Data diolah, 2018

Berdasarkan Tabel 8 menunjukkan hasil pengolahan data dengan menggunakan Eviews versi 8.0di peroleh regresi linier berganda untuk menghitung produksi kelapa sawit kelompok tanidi Desa Purwodadi Kecamatan Tebing Tinggi Kabupaten Tanjung Jabung Barat yang dipengaruhi dengan variabel bebas diantaranya modal, luas lahan, dantenaga kerja. Persamaan regresi sebagai berikut :

$$
\begin{aligned}
& \log Y=\beta_{0}+\log X_{1}+\log X_{2}+\log X_{3}+\mathbf{e}^{\mathbf{u}} \\
& \log Y=17,79482+0,420714 \log X_{1}+0,903379 \log X_{2}+0,255833 \log X_{3}
\end{aligned}
$$

Berdasarkan hasil pengolahan data yang di peroleh maka dapat disimpulkan menjadi: (1) Nilai konstanta sebesar 17,79482 yang berarti jika modal, luas lahan, dantenaga kerja tetap maka produksi kelapa sawit kelompok tani di Kecamatan Tebing Tinggi sebesar 17,79 Ton. (2) Koefisien regresi modal sebesar 0,420714 maka apabila modal mengalami peningkatan 1 persen maka produksi kelapa sawit kelompok tani diKecamatan Tebing Tinggi meningkat sebesar 0,42 persen. (3) Koefisien regresi luas lahan sebesar 0,903379 maka apabila tenaga kerja mengalami penambahan sebesar 1 persen maka produksi kelapa sawit kelompok tani di Kecamatan Tebing Tinggi meningkat sebesar 0,90 persen. (4) Sedangkan koefisien regresi tenaga kerja sebesar 0,255833 maka apabila tenaga Kerja mengalami penambahan sebesar 1 persen maka produksi kelapa sawit kelompok tani di Kecamatan Tebing Tinggi meningkat sebesar0,25 persen.

Berdasarkan hasil pengolahan data produksi kelapa sawit akan meningkat diperoleh dari koefisien regresi masing-masing variabel modal sebesar 0,42, luas lahan sebesar 0,90 dan tenaga kerja sebesar 0,25 yang berarti variabel modal, luas lahan dantenaga kerja berpengaruh posistif dan signifikan terhadap produksi kelapa sawit kelompok tani di Desa Purwodadi Kecamatan Tebing Tinggi Kabupaten Tanjung Jabung Barat. Apabila modal,luas lahan dan tenaga kerja ditambah maka produksi kelapa sawit pun akan meningkat.

\section{Koefisien determinasi $\left(\mathbf{R}^{2}\right)$}

Melalui koefisien Deteminasi (Adjusted R Square) dapat diketahui sejauh mana variabel modal, tenaga kerja, dan luas lahan mampu mempengaruhi produksi kelapa sawit kelompok tani di Desa Purwodadi Kecamatan Tebing Tinggi Kabupaten Tanjung Jabung Barat. Semakin mendekati nilai 1 atau $100 \%$ maka semakin besar pengaruh variabel independen terhadap variabel dependen. Berdasarkan hasil R-square sebesar 0,470583 atau 
47,05\%. Hal ini menunjukkan bahwa persentase pengaruh variabel independen (modal,luas lahan dantenaga kerja) terhadap variabel dependen (Produksi kelapa sawit) sebesar $47,05 \%$. Sedangkan 52,95\% dipengaruhi variabel yang belum diteliti dalam penelitian ini.

\section{Uji simultan (Uji F )}

Uji F digunakan untuk mengetahui semua variabel independen yang terdapat dalam persamaan regresi secara bersama-sama mempengaruhi variabel dependen. Pengujian dilakukan dengan membandingkan nilai $\mathrm{F}$ hitung dengan $\mathrm{F}$ tabelmenggunakan tingkat keyakinan 95\% $(\alpha=5 \%)$. Hasil perhitungan diperoleh nilai $\mathrm{F}$ hitung sebesar 0,007198 dengan p-value sebesar 0.000068 , dan nilai $F$ tabelsebesar 0,276 . Oleh karena $F$ hitung $(0,007)<\mathrm{F}$ tabel $(0,276)$ dapat disimpulkan bahwa terdapat pengaruh yang signifikan produksi kelapa sawit kelompok tani di Desa Purwodadi Kecamatan Tebing Tinggi Kabupaten Tanjung Jabung Barat pada tingkat keyakinan 95\%. Hasil tersebut menunjukkan bahwa hipotesis penelitian ini yaitu pengaruh modal, luas lahan dantenaga kerja secara simultan berpengaruh signifikan terhadap produksi kelapa sawit kelompok tani di Desa Purwodadi Kecamatan Tebing Tinggi Kabupaten Tanjung Jabung Barat.

\section{Uji parsial (Uji t)}

Pengujian secara parsial atau uji t dimaksudkan untuk mengetahui apakah variabelvariabel independen secara sendiri-sendiri berpengaruh nyata atau tidak terhadap variabel dependen. Dalam penelitian ini menggunakan uji 2 arah. Dengan keyakinan 95\% $(\alpha=5 \%)$ serta derajat kebebasan (df) sebesar 11, maka ttabel diperoleh 1,671. Dari hasil ujihipotesis yang dilakukan secara parsial modal, luas lahan dantenaga kerja berpengaruh posistif signifikan terhadap produksi kelapa sawit kelompok tani di Desa Purwodadi Kecamatan Tebing Tinggi Kabupaten Tanjung Jabung Barat ditunjukkan dengan nilai thitung modal sebesar 3,624 atau $1,967 \%$ dan ttabelsebesar 1,671, nilai thitung $>\operatorname{ttabel}(3,624>$ 1,671),luas lahan sebesar 2,650 atau 2,560\% dan ttabelsebesar 1,671, nilai thitung $>$ ttabel $(2,560>1,671)$,sedangkan tenaga kerja sebesar 0,811 atau $0,811 \%$ dan ttabelsebesar 1,671 , nilai thitung $>\operatorname{ttabel}(0,811<1,671)$. . Dengan level signifikansi variabel produksi kelapa sawit adalah sebesar $0,0086<0,05$.

\section{Asumsi klasik}

\section{Uji linieritas}

Linieritas merupakan asumsi awal yang seharusnya ada dalam model regresi linier. Uji normalitas data bertujuan untuk menguji apakah dalam model regresi, variabel terikat (dependen) dan variabel bebas (independen) memiliki distribusi normal. Uji linieritas dapat dengan mudah dilakukan pada regresi linier sederhana, yaitu membuat scatter diagram dari variabel bebas dan variabel terikatnya. Apabila scatter diagram menunjukkan bentuk garis lurus maka dapat dikatakan bahwa asumsi linieritas terpenuhi.Untuk regresi linier berganda, pengujian terhadap linieritas dapat menggunakan RamseyReset Test.

Tabel 9. Hasil uji linieritas

\begin{tabular}{llll}
\hline & Value & Df & Probablity \\
\hline $\begin{array}{l}\mathrm{T}- \\
\text { stayistic }\end{array}$ & 2.215216 & 33 & 0.0338 \\
$\mathrm{~F}-$ & 4.907183 & 1,33 & 0.0338 \\
statistic & & & \\
Likelihood ratio & 5.268056 & 1 & 0.0217 \\
\hline Suber
\end{tabular}

Sumber : Data diolah, 2018 
Berdasarkan Tabel 9. apabila nilai Prob. F hitung lebih besar dari tingkat alpha 0,05 (5\%) maka model regresi memenuhi asumsi linieritas dan sebaliknya, apabila Prob. F hitung lebih kecil dari 0,05 maka model tidak memenuhi asumsi linieritas. Nilai Prob. F hitung dapat dilihat pada baris F-statistic kolom probability. Pada kasus ini nilainya 0,0338 lebih kecil dari 0,05 sehingga dapat disimpulkan bahwa model regresi memenuhiasumsi linieritas.

\section{Uji normalitas}

Uji normalitas dilakukan untuk mengetahui apakah variabel independen ataupun variabel dependen mempunyai distribusi normal atau tidak. Modelregresi yang baik adalah distribusi data normal atau mendekati uji normalitas. Keputusan terdistribusi normal tidaknya residual secara sederhana dengan membandingkan nilai probabilitas JB (JargueBera) hitung dengan tingkat alpha 0,05 ( 5\%).

Apabila Prob. JB hitung lebih besar dari 0,05 maka dapat disimpulkan bahwa residual terdistribusi normal dan sebaliknya, apabila nilainya lebih kecil maka tidak cukup bukti untuk menyatakan bahwa residual terdistribusi normal.

Nilai Prob. JB hitung sebesar 0,136349 >0,05 sehingga dapat disimpulkan bahwa residual terdistribusi normal yang artinya asumsi klasik tentang kenormalan terpenuhi.

\section{Uji multikoliniearitas}

Tujuan dari uji multikoliniearitas adalah untuk menguji apakah di dalam model regresi ditemukan adanya korelasi di antara variabel bebas (variable independent). Model regresi yang baik seharusnya tidak terjadi korelasi di antara variabel bebas. Metode pengujian yang biasa digunakan yaitu dengan melihat nilai Variance Inflation Factor tolerance pada model regresi. Jika nilai VIF kurang dari 10 dan tolerance lebih dari 0,1 maka model regresi bebas dari multikoliniearitas.

Tabel 10. Hasil uji multikolinieritas

\begin{tabular}{lccc}
\hline Variable & Coeficienetvariable & Uncentered VIF & Centered VIF \\
\hline C & 70.45376 & 5.784155 & NA \\
MD & 0.528480 & 3.483557 & 0.000690 \\
LH & 0.124442 & 3.061716 & 0.000603 \\
TK & 0.099364 & 2.7455487 & 0.000343 \\
\hline
\end{tabular}

Sumber: Data diolah, 2018

Berdasarkan Tabel 10. Hasil uji multikolinieritas, dapat dilihat pada tabel kolom Contered VIF. Nilai VIF untuk variabel MD, LH dan TK adalah 0,000690 , 0,000603 dan 0,000343 tidak ada yang lebih besar dari 10 atau 5 (banyak buku yang mensyaratkantidak lebih dari 10, tapi ada yang mensyaratkan tidak lebih dari 5) maka dapat dikatakantidak terjadi multikolinieritas pada ke tiga variabel tersebut. Berdasarkan syarat asumsi klasik regresi linier dengan OLS, maka model regresi linier yang baik adalah yang terbebas dari adanya multikolinieritas.

\section{Uji autokorelasi}

Nilai Prob. $F(2,32)$ sebesar 0,0059 dapat juga disebut sebagai nilai probabilitas $F$ hitung. Nilai Prob. F hitung lebih besar dari tingkat alpha 0,05 (5\%) sehingga berdasarkan hipotesis, H0 diterima yang artinya tidak terjadi autokorelasi. Sebaliknya apabila nilai Prob. F hitung lebih kecil dari 0,05 maka dapat disimpulkan terjadi aotukorelasi. 
Tabel 11. Hasil uji autokorelasi

\begin{tabular}{llll}
\hline F-Statistic & 0.90176 & Prob. F(2,23) & 0.0059 \\
Obs*R-Squared & 2.027491 & Prob. Chi Square(2) & 0.0029 \\
\hline
\end{tabular}

Sumber : Data diolah, 2018

Berdasarkan Tabel 11 menunjukkan nilai Prob. F(2,32) sebesar 0,0059 dapat juga disebut sebagainilai probabilitas F hitung. Nilai Prob. F hitung lebih besar dari tingkat alpha 0,05 (5\%) sehingga berdasarkan hipotesis, $\mathrm{H}_{0}$ diterima yang artinya tidak terjadi autokorelasi. Sebaliknya apabila nilai Prob. F hitung lebih kecil dari 0,05 maka dapat disimpulkan terjadi aotukorelasi.

\section{Uji heteroskedastisitas}

Uji heteroskedastisitas bertujuan untuk memastikan dalam model regresi terjadi kesamaan variance dari residual satu pengamatan lain. Model regresi yang baik tidak terjadi heteroskedastisitas.

Tabel 12. Hasil uji heteroskedastisitas

\begin{tabular}{lclr}
\hline F-statistic & 1.392961 & Prob. F(3,34) & 0.0267 \\
$\begin{array}{l}\text { Obs*R- } \\
\text { squared }\end{array}$ & 4.159304 & $\begin{array}{l}\text { Prob. Chi- } \\
\text { Square(3) }\end{array}$ & 0.0248 \\
Scaled explained & 3.894450 & Prob. Chi-Square(3)0.0273 \\
\hline
\end{tabular}

Sumber: Data diolah, 2018

Berdasarkan Tabel 12 menunjukkan uji statistik untuk mengetahui model lulus atau tidaknya dari heteroskedastisitas dengan menggnakan uji Breusch-Pagan-Godfrey. Diperoleh hasildari pengujian ini nilai F-statistik (F hitung) sebesar 0,0267 lebih besar dari tingkat alpha0,05 $(5 \%)$ maka $\mathrm{H}_{0}$ diterima yang artinya tidak terjadi Heteroskedastisitas.

\section{KESIMPULAN DAN SARAN}

\section{Kesimpulan}

Berdasarkan karakteristik sosial ekonomi petani kelapa sawit di Desa Purwodadi Kecamatan Tebing Tinggi Kabupaten Tanjung Jabung Barat dapat dilihat dari kelompok responden berdasarkan rata-rata jenis kelamin laki-laki sebanyak 68 persen, rata-rata tingkat pendidikanSLTA sebanyak47 persen dan rata-rata pengalaman kerja 21-30 tahunsebanyak 37persen, rata-rata jumlah tenaga kerja 11-15 orangsebanyak39 persen, rata-rata luas lahan 5-8 hektarsebanyak42 persen, rata-rata modal $\leq \mathrm{Rp} 10.000 .000$ sebanyak37 persen dan rata-rata produksi kelapa sawit 21-30 tonsebanyak53 persen.Berdasarkan hasil penelitian dapat disimpulkan bahwa variabel modal, luas lahan dantenaga kerja terbukti berpengaruh positif dan signifikan terhadap produksi kelapa sawit kelompok tani di Desa Purwodadi Kecamatan Tebing Tinggi Kabupaten Tanjung Jabung Barat.

\section{Saran}

Penelitian ini diharapkan bisa menjadi acuan bagi para pembaca sehingga menambah wawasan dalam upaya peningkatan produksi kelapa sawit. Pengaruh modal, luas lahan dan tenaga kerja terhadap produksi kelapa sawit kelompok tani di Desa Purwodadi Kecamatan Tebing Tinggi Kabupaten Tanjung Jabung Barat sangat signifikan, disarankan untuk Pemerintah Kabupaten berperan aktif untuk membantu kelancaran petani dalam mengolah lahan dengan memberikan bantuan modal dan perluasan lahan serta pemasaran hasil panen kelapa sawit. 


\section{DAFTAR PUSTAKA}

Anonim. (2016). Produksi kelapa sawit di Kabupaten Tanjung Jabung Barat: Jambi.

Daim,Chamidun. (2003). Pengembangan kemitraan dan dukungan pendanaannya di Bidang Perkebunan. IPB: Bogor.

D Hastuti, A Delis, R Rosmeli. (2018).Pengembangan komoditas kelapa sawit dan karet serta dampaknya terhadap pendapatan petani di Kecamatan Pelepat Ilir, Jurnal Sains Sosio Humaniora, 2 (2), 92-104

Daniel, Moehar. (2004). Pengantar ekonomi pertanian. Bumi Aksara: Jakarta.

Hernanto, F.(1988). Ilmu usahatani. Penebar Swadaya: Jakarta.

Kartasapoetra, A.G. (1987). Pengantar ekonomi produksi pertanian. BinaAksara: Jakarta. Mosher, A. T. (1985). Menggerak dan membangun pertanian. CV. Jasa Guna: Jakarta.

Mubyarto. (1989). Pengantar ekonomi pertanian. LP3ES Rajawali Pers: Jakarta.

S Hodijah. (2020). The impact of eu palm oil resolution on the performance of asean macroeconomic and trade and change in world society welfare, South East Asia Journal of Contemporary Business, Economics and Law, 21(2), 38-49

Soeharjo, dkk. (1980). Metode riset untuk bisnis \& ekonomi. Erlangga:Jakarta.

Soekartawi. (2003). Teori Ekonomi Produksi dengan Pokok Bahasan Analisis Cobb Douglas. PT Raja Grafindo Persada: Jakarta, 250 hal.

Sugiyono. (2011). Metode penelitian kuantitatif kualitatif dan R\&D. Alfabeta:Bandung.

Sumodiningrat, G dan Iswara, A.L. (1987). Ekonomi produksi. Karunika: Jakarta.

Suprayitno. (1996). Pengantar ekonomi makro. BPFE: Yogyakarta.

Suratiah, Ken. (2006). Ilmu Usahatani. Penebar Swadaya: Depok.

Umar, Husein. (2005). Metode penelitian untuk skripsi dan tesis bisnis. PT. RajaGrafindo Persada: Jakarta. 